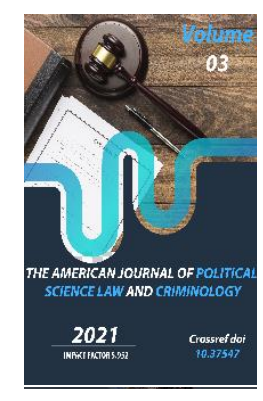

\title{
Features Of Uzbekistan's Experience In Ensuring Equal Rights Of Women And Men
}

\author{
Shahnoza Nuritdinovna Gaffarova \\ Doctoral Student, Tashkent State University Of Law, Uzbekistan
}

Journal Website: http://usajournalshub.c om/index,php/tajpslc

Copyright: Original content from this work may be used under the terms of the creative commons attributes 4.0 licence.

\section{ABSTRACT}

This article examines the work done in recent years to ensure gender equality in the Republic of Uzbekistan. Views were expressed on the ratification by the Republic of Uzbekistan of international conventions and treaties on the protection of women's rights and the implementation of the norms set out in these internationally recognized documents in national legislation. The legislation of Uzbekistan analyzes the norms for raising the issue of gender equality to the level of state policy and protecting women's rights in normative legal acts. A number of scientific opinions on gender equality issues were cited. A number of practical problems on the issue of equality of women and men in the conditions of Uzbekistan were discussed, as well as some theoretical and practical proposals for their solution were proposed.

\section{KEYWORDS}

Equality, gender equality, women's rights, international conventions, implementation, Labor Code, Family Code, Parliament, Address, women's literacy.

\section{INTRODUCTION}

Since the first years of independence, wide range of works has been carried out in the
Republic of Uzbekistan to ensure equal rights for women and men, and protect motherhood 
and childhood. Special attention was paid to the establishment of legal and practical framework for ensuring gender equality.

Article 46 of the Constitution of the Republic of Uzbekistan, adopted in 1992, is considered to be a practical example of this issue. That is, in this article, the norm "Women and men have equal rights" is strengthened'. The current basis indicates that the issue of gender equality was an important practical step in the early years of independence.

The socio-political and spiritual stability of women in society depends on their attitude and attention to the youth and family. Such issues as strengthening the role of women in our country, creating the necessary conditions for them to acquire modern education, healthy and strong families, and protecting the health of mothers and children are identified as priorities of state policy.

Uzbekistan was also one of the first Central Asian States to take a number of measures to ensure equal rights for women with men. In 1995, Uzbekistan ratified the Convention on the Elimination of All Forms of Discrimination against Women (CEDAW) ${ }^{2}$, and a number of its

\footnotetext{
${ }^{1}$ https://lex.uz/docs/4032775

2

https://www.ohchr.org/en/professionalinterest/pages/ cedaw.aspx

3 https://www.un.org/en/about-us/universaldeclaration-of-human-rights

4

https://www.ohchr.org/en/professionalinterest/pages/ crc.aspx

5

https://www.ohchr.org/en/professionalinterest/pages/ cedaw.aspx

https://www.ilo.org/dyn/normlex/en/f?p=NORMLEX

PUB:12100:0::NO::P12100_ILO_CODE:C100
}

articles were incorporated into national legislation.

\section{MAIN PART}

Over the years of independence, Uzbekistan has signed and acceded to many important international documents aimed at the equality of women and men. In particular, the "Universal Declaration of Human Rights", the Convention "On the Rights of the Child", the Convention "On the Elimination of All Forms of Discrimination against Women", the Declaration "On Equal Remuneration for Men and Women for Work of Equal Value"6, "Convention against Discrimination in Education", the Convention "On the Political Rights of Women", the Convention "On Discrimination in Work and Employment", the Declaration "On the Elimination of All Forms of Intolerance and of Discrimination Based on Religion or Belief"10 and others ${ }^{11}$.

On the basis of international norms and standards in the field of human rights, significant work has been carried out in Uzbekistan to harmonize national legislative acts, and more than 100 legislative acts on the rights and freedoms of citizens have been adopted.

\footnotetext{
7 http://portal.unesco.org/en/ev.phpURL_ID=12949\&URL_DO=DO_TOPIC\&URL_SE CTION=201.html

${ }^{8}$ http://hrlibrary.umn.edu/instree/e2cprw.htm

9 https://www.ilo.org/wcmsp5/groups/public/--ed_norm/---

declaration/documents/publication/wcms_decl_fs_85 _en.pdf

https://www.ohchr.org/en/professionalinterest/pages/r eligionorbelief.aspx

${ }^{11}$ Review of the current legislation of the Republic of Uzbekistan. T, 1999, p. 10.
} 
A wide range of activities is being carried out in our country to increase the socio-political and social activity of women and girls, to create conditions for them to realize their abilities and opportunities in various fields and industries, to ensure unconditional respect for their rights and legitimate interests, to fully support motherhood and childhood, as well as to strengthen their health.

At the same time, it is noted that the state of affairs in this area is evidenced by the presence of a number of systemic problems and shortcomings that prevent comprehensive support for women in all spheres, the organization of purposeful work with them, the strengthening of the moral environment in families and the creation of effective health care institutions, improving the quality of life of women. In fact, this shows that women do not give them the opportunity to fully mobilize their strength and capabilities when it comes to solve the most important problems.

It is also necessary to ensure the effective implementation of state policies to support women, protect their rights and legitimate interests, as well as to increase their role and activity in the socio-political life of the country.

In his Address to the Oliy Majlis on December 29, 2020, President of the Republic of Uzbekistan SH.M.Mirziyoyev noted that "strengthening the role and position of women in state and public administration is the most priority area of reforms", and analyzed the results of the positive growth of the role of women in public administration in recent years. In his speech, the President noted that "the task facing our state is to increase the prestige

\footnotetext{
${ }^{12}$ https://president.uz/en/lists/view/4047
}

of women in society, and proposed as a next step to create a Republican Women's Public Council, which will include initiative women who are well aware of women's problems, in order to create more opportunities for women"12.

In general, the head of our state will address the issue of women, practical reforms related to ensuring their rights and freedoms, and plans for the future in each of his speeches.

In particular, at the 75th session of the UN General Assembly on September 23, 2020, President of the Republic of Uzbekistan Shavkat Mirziyoyev pointed: "As a result of our large-scale measures for the political, social and economical modernization of society, a new Uzbekistan is being formed. Today, the democratic changes in our country have taken such a turn that you can't go back.

The gender equality policy became a priority for us. The role of women in public administration is growing. In our new Parliament the number of women deputies has doubled"'.

The Convention on the Elimination of All Forms of Discrimination against Women has been ratified by some States under additional conditions, which means that much remains to be done in this regard. But the norms adopted by the majority of States on the protection of women from various forms of violence, protection of motherhood, ensuring equality in the sphere of work, active participation of women in political and social processes, and support for defenseless women have been adopted by the majority of States.

13 https://www.un.int/uzbekistan/news/speechpresident-republic-uzbekistan-he-mr-shavkatmirziyoyev-75th-session-united-nations 


\section{RESULTS AND DISCUSSIONS}

Consistent measures are being taken in the Republic to implement women's rights, develop gender legislation, and improve the legislative framework and norms. In the process of improving the legislative framework, laws were adopted aimed at the following. In particular, attention was paid to the protection of women's rights in family and marriage relations, efforts to prevent violence, and the fight against outdated patriarchal stereotypes ${ }^{14}$.

Thus, the legislation of the Republic of Uzbekistan fully complies with international standards, and from a legal point of view, we do not have the opportunity to create advantages of one sex over the other. For example, the restrictions that prohibit women from working in difficult and harmful working conditions that exist in the labor legislation, as well as the fact that women actively participate in the performance of maternal duties and social life (part-time work, an abundance of vacation time, etc.). and the use of incentive benefits are not considered discriminatory under international law, that is, it is a specific positive discrimination ${ }^{15}$. In our opinion, for the same reason, it is impossible to deny the physiological properties of the female body.

The norms established by the Labor, Family and other codes of the Republic of Uzbekistan are aimed at ensuring equality between women and men. However, in some places, women are also given certain preferences. In particular,

14 Twenty-fifth anniversary of the Fourth World Conference on Women and the adoption of the Beijing Declaration and Platform for Action (1995). Report on the implementation of the provisions of the Beijing Declaration and Platform for Action Uzbekistan. 2019. article 16 of the Labor Code of the Republic of Uzbekistan defines in accordance with the Constitution of the Republic of Uzbekistan: "everyone has the right to work, to freely choose their place of work, to work on the basis of fair working conditions, and to be protected from unemployment in accordance with the procedure established by law"16.

Article 78 of the Labor Code establishes procedures for preventing illegal refusal of employment. According to this article ${ }^{17}$, an employer has no right not to employ people who are required by law to conclude an employment contract (people employed at the expense of the established minimum number of jobs; pregnant women and women with children under three years of age - on the basis that they are pregnant or have children, respectively).

Chapter XIV of the Labor Code deals with additional guarantees and benefits that are provided to employees of certain categories. Article 224 "Guarantees for the employment of pregnant women and women with children", Article 225 "Work in which the use of women's labor is prohibited", article 226 "Transfer of pregnant women to easier or non-harmful work factors", Article 227 "transfer of women with children under two years of age to work exposed to lighter or unfavorable factors of production, when working on weekends, there are restrictions on the use of women's labor and sending them on a business trip", other perks and amenities are also provided. And in

15 Cherkashina I. In the field of Gender law and management. Legislative basis of Gender equality. // Introduction to Gender relationship theory and practice. Collection of scientific articles T.: 2007. P.189

16 https://cis-legislation.com/document.fwx?rgn=974

${ }^{17} \mathrm{https}$ ://cis-legislation.com/document.fwx?rgn=974 
article 289 it is established that "the old-age pension is assigned to employees who are insured on a general basis: men-sixty years, and women-fifty-five years, if the total work experience is not less than twenty-five years, then the total work experience is assigned at least twenty years".

Both women and men have the right to choose their own profession. No one can be forced to accomplish what they don't want to do. International human rights standards and the requirements of national legislation prohibit forced labor.

After all, the state protection of gender equality is a reform of discriminatory norms based on democratic principles and their implementation in practice. The norms established by the state, national rules, must be implemented by society, public organizations and state bodies.

The Family Code of the Republic of Uzbekistan defines the norms aimed at protecting the interests of women in the family.

In particular, article 3 of the Family Code establishes the equality of citizens in family relations, according to which "all citizens have equal rights in family relations. When entering into a marriage, depending on gender, race, nationality, language, religion, social origin, nationality, personal and social status, as well as other circumstances, it is not allowed to directly or indirectly restrict rights in a certain way, establish direct or indirect advantages and interfere in family relations". Article 14 of the Code establishes the exclusivity of marriage, according to which "for the purposes of marriage, the future couple must

\footnotetext{
${ }^{18}$ https://cis-legislation.com/document.fwx?rgn=973
}

be able to freely express their consent. Forced marriages are forbidden"18.

In addition, chapter 4 of the Family Code defines the personal rights and obligations of spouses. In particular, article 18 of the Code defines "the existence of the rights and obligations of spouses", and article 19 "equality of husband and wife in the family". And Chapter 5 of the Family Code establishes the property rights and obligations of the husband and wife.

According to S.Baratova, the Chairman of the Senate of the Oliy Majlis of the Republic of Uzbekistan on Women and Gender equality, the law on gender Equality "guarantees equal rights for women and men in the exercise of personal, political, economical, social and cultural rights. The same guarantee provides for the provision of equal rights and opportunities in the areas of public administration, equal participation in the electoral process, health, education, science, culture, labor and social protection, as well as in other areas of public and public lives. Most importantly, true equality between women and men will be achieved in all areas, especially if our society as a whole understands and fully understands the essence of this law"19.

Issues of international cooperation for the protection of women's rights in Uzbekistan are of paramount importance for improving the national legislative framework aimed at equalizing the opportunities of women and men in Uzbekistan.

Because there is a concrete experience of ensuring gender equality in the leading countries of the world. In particular, since 1996,

19 https://uza.uz/uz/posts/khotin-izlar-va-erkaklarrtasida-a-i-iy-tenglikka-achon-erish-26-09-2019 
the European Commission has been monitoring the implementation of a comprehensive approach to gender equality. Reports are published under the general title "Equal opportunities for women and men in the European Union" on issues of ensuring equality between women and men. The special significance of the world community's approach to gender equality lies in the fact that this approach unites the interests and dignity of women.

According to I.Cherkashina, who conducted scientific research in the same field, this is directly related to the full realization of all the rights and freedoms granted to women to improve their position in society, increase their status. The State is obliged to support this, to protect the rights and legitimate interests of women ${ }^{20}$.

In our opinion, when reforming the issue of gender equality, the state's protective measures can be manifested in the following types:

- Reform of legislation, improvement and elimination of discriminatory norms against women;

- Elimination of shortcomings in the legislation that deprive women of the right to self-defense;

- Monitoring of practical compliance with the norms introduced into the recognized international and national legislation ensuring women's rights and interests;

- Increasing legal literacy of women;

- It is necessary to expand the network of public organizations that directly deal with

${ }^{20}$ Cherkashina I. Measures of legal protection and promotion of gender equality. Introduction to the theory of gender relations. Introduction to the theory women's issues, and to support them from the state.

In accordance with the accepted international requirements, women's working volume in public administration bodies, organizations and institutions must make up at least 30\% of the total number of employees. This norm is also enshrined in the documents adopted in the Republic of Uzbekistan.

It should be noted that the introduction of quotas for creating equal conditions in Parliament and self-government bodies in order to increase women's political activity is an important effect of ensuring equality between women and men.

Special attention is paid to the socio-political activity of women in the electoral system. The provision that at least 30 percent of candidates from political parties are women indicates that the electoral legislation complies with international requirements.

At the beginning of 2002, women accounted for $13.7 \%$ of the senior management bodies in Uzbekistan, while men accounted for $86.3 \%$. In the legislative and representative bodies, the proportion of women was $12.3 \%$, men $87.7 \%$, in the executive authorities $15.3 \%$ and $84.7 \%$, respectively, in the judiciary $20.3 \%$ and $79.7 \%,{ }^{21}$.

The Election Code of the Republic of Uzbekistan has introduced a provision that the number of women must be at least thirty

of gender relations. // Collection of scientific articles. - Vol.: 2007. 233-p.

${ }^{21}$ Women and men of Uzbekistan. Article. collection. T., 2002. p. 101. 
percent of the total number of candidates for these deputies from a political party ${ }^{22}$.

In his congratulatory message on the occasion of International Women's Day on March 8, 2020, President of the Republic of Uzbekistan Sh.Mirziyoyev said: "Thanks to mothers, our country is peaceful, the sky is clear, our work is fruitful and our life is blessed. The country pays great attention to women's rights and gender equality. In addition to caring for their families, women are also actively involved in public and public affairs. Of the 150 deputies elected to the Legislative Chamber of the Oliy Majlis, 32\% were women. In the Senate and local councils, this figure exceeds 25 percent. For the first time in Uzbekistan's history, the number of women in the national parliament has reached the level set by the United Nations. The legislative body of our country has risen to $37^{\text {th }}$ place among 190 national parliaments in the world in terms of the number of women deputies. However, 5 years ago, we were in $128^{\text {th }}$ place" 23 .

If we compare the share of women in the parliaments of other countries of the world, then women in the parliament of the State of Israel make up $27.5 \%$, in Sweden-43.6\%, in Finland-42\%, in Norway-41.4\%, in Iceland$38.1 \%{ }^{24}$.

World experience shows that the solution of many problems in the field of ensuring women's rights largely depends on the culture of equality of men and women in society, the culture of gender relations. And this cannot be

\footnotetext{
22 https://lex.uz/docs/4458857

${ }^{23} \mathrm{https} / / /$ president.uz/uz/lists/view/3431

${ }^{24}$ Abdieva F. Increasing the role of women in public administration: problems and ways to solve them. Collection of articles of the Republican scientific and practical conference on the topic "Increasing the sociopolitical activity of women - an important factor of the
}

achieved without raising a woman in a respectful relationship as a person, without raising her status, without improving her position in the family and society, without strengthening her legal status. For this reason, it is increasingly important to create a clear legal framework for the protection and enforcement of women's rights, a favorable social environment for women, strengthening their status in the family and society, and increasing participation in State power structures. At the same time, in the national mechanism for the implementation of international human rights standards, the importance of coordinated work of various associations, the activities of women's and women's public associations to protect the rights of men and women are increasing. The legal and organizational conditions created in Uzbekistan for women's participation in public and public life are an important area of State policy ${ }^{25}$.

Unfortunately, “women's low self-esteem remains an extremely worrying principle. Gender inequality is considered the norm of life, they are even more patriotic than men. Teenagers naturally accept the withdrawal of women from the political scene and the long silence that reigns over family problems".

Without training women for leadership and responsible decision-making, it is difficult to imagine the development of civil society, the strengthening of democratic reforms, and the

reforms carried out in our country". - T.: "ECONOMY-FINANCE", 2019. - p. 82

${ }^{25}$ Akhmedshina F. Gender problems of Uzbekistan in the conditions of independence. Introduction to the theory of gender relations. Introduction to the theory of gender relations. // Collection of scientific articles. - T.: 2007. P. 413-415 
development of various public and women's organizations.

Gender equality between men and women the development of the legal and political culture necessary for women for social changes in society, the further promotion of which is necessary. Women's legal and political literacy provides a practical basis for strategic changes in society.

Currently, women are involved not only in political reforms, but also in the implementation of legal reforms. The participation of women widows in the reforms undertaken to ensure gender equality in society, especially the participation of legal scholars and women practitioners, contributes to further improving the consistency and effectiveness of hymns conducted in the field of gender equality.

\section{CONCLUSION}

To recapitulate, it is worth noting that now almost all countries take into account the interests and needs of women. They participate in the processes of public administration and decision-making.

The effective use of the equal rights of women and men is seen as a fundamental value of sustainable development. There is a consensus on the empowerment of women in all areas.

It is necessary to continue practical actions aimed at changing the negative attitude of women to gender equality in society, removing obstacles to improve the social status of women, respecting their views and rights, and preventing discrimination and violence as a result of gender inequality.

Although the law prohibits any discrimination on the basis of sex and provides a legal framework for protecting women's rights in the labour market, its practical effect is not the same in all areas. The expected results will not be achieved if the implementation of the adopted legal acts on ensuring equality of women and men is not strengthened by the coercive power of the State. At the same time, the principle of the inevitability of responsibility must be ensured. The adoption of judicial measures against violations of the law in cases of insufficient protection of the legitimate interests of women will contribute to improving the effectiveness of work to ensure equality between women and men.

It is necessary to increase the number of politically-active, legally-educated and spiritually-educated women in society, to expand their participation in state and public administration.

Providing women with privileged access to higher education institutions, depending on their appearance in the districts, attracting women's working in public administration bodies, organizations and institutions that give birth and leave for childcare to online training courses serves to prevent cases of lag in the acquisition of modern knowledge and skills of women.

Keeping a clear record of women in need of social protection is necessary to further expand measures to provide them with guaranteed assistance from the State, as well as to develop effective monitoring of the protection of women's rights and further improve existing opportunities.

\section{REFERENCES}

1. https://lex.uz/docs/4032775

2. https://www.ohchr.org/en/professionalint erest/pages/cedaw.aspx 
3. https://www.un.org/en/aboutus/universal-declaration-of-human-rights

4. https://www.ohchr.org/en/professionalint erest/pages/crc.aspx

5. 5.https://www.ilo.org/dyn/normlex/en/f?p =NORMLEXPUB:12100:0::NO::P12100_ILO CODE:C100

6. http://portal.unesco.org/en/ev.phpURL_ID $=12949 \& U R L \_D O=D O \_T O P I C \& U R$ L_SECTION=201.html

7. http://hrlibrary.umn.edu/instree/ezcprw.h tm

8. https://www.ilo.org/wcmsp5/groups/publi c/---ed_norm/--declaration/documents/publication/wcms _decl_fs_85_en.pdf

9. https://www.ohchr.org/en/professionalint erest/pages/religionorbelief.aspx

10. Review of the current legislation of the Republic of Uzbekistan. T, 1999, p. 10.

11. https://president.uz/en/lists/view/4047

12. https://www.un.int/uzbekistan/news/spee ch-president-republic-uzbekistan-he-mrshavkat-mirziyoyev-75th-session-unitednations

13. Twenty-fifth anniversary of the Fourth World Conference on Women and the adoption of the Beijing Declaration and Platform for Action (1995). Report on the implementation of the provisions of the Beijing Declaration and Platform for Action Uzbekistan. 2019.

14. Cherkashina I. In the field of Gender law and management. Legislative basis of Gender equality. // Introduction to Gender relationship theory and practice. Collection of scientific articles T.: 2007. P.189

15. https://cislegislation.com/document.fwx?rgn=974
16. https://cislegislation.com/document.fwx?rgn=974

17. https://cislegislation.com/document.fwx?rgn=973

18. https://uza.uz/uz/posts/khotin-izlar-vaerkaklar-rtasida-a-i-iy-tenglikka-achonerish-26-09-2019

19. Cherkashina I. Measures of legal protection and promotion of gender equality. Introduction to the theory of gender relations. Introduction to the theory of gender relations. // Collection of scientific articles. - Vol.: 2007. 233-p.

20. Women and men of Uzbekistan. Article. collection. T., 2002. p. 101.

21. https://lex.uz/docs/4458857

22. https://president.uz/uz/lists/view/3431

23. Abdieva F. Increasing the role of women in public administration: problems and ways to solve them. Collection of articles of the Republican scientific and practical conference on the topic "Increasing the socio-political activity of women - an important factor of the reforms carried out in our country". - T.: "ECONOMYFINANCE", 2019. - p. 82

24. Akhmedshina F. Gender problems of Uzbekistan in the conditions of independence. Introduction to the theory of gender relations. Introduction to the theory of gender relations. // Collection of scientific articles. - T.: 2007. P. 413-415 